\title{
Inheritance of resistance to spotted stem borer, Chilo partellus, in sorghum, Sorghum bicolor
}

\author{
H. C. Sharma · M. K. Dhillon · G. Pampapathy • \\ B. V. S. Reddy
}

Received: 4 June 2006/ Accepted: 10 January 2007/Published online: 2 February 2007

(C) Springer Science+Business Media B.V. 2007

\begin{abstract}
The spotted stem borer, Chilo partellus, is one of the most important pests of sorghum, and host plant resistance is an important component for the management of this pest. Most of the sorghum hybrids currently under cultivation are based on cytoplasmic male-sterility (CMS). In order to develop a strategy for resistance to stem borer, we studied the traits associated with resistance, and their nature of gene action in $\mathrm{F}_{1}$ hybrids derived from resistant, moderately resistant, and susceptible CMS and restorer lines. The hybrids based on stem borerresistant, moderately resistant, or susceptible CMS and restorer lines were equally resistant or susceptible as the parents for leaf feeding [Damage rating (DR) 5.8 to 6.6 vs. 5.9 to 6.6], and had significant and decreasing trend in deadheart formation (resistant CMS $\times$ resistant restorer lines $<$ moderately resistant $\mathrm{CMS} \times$ moderately resistant restorer lines $<$ susceptible $\mathrm{CMS} \times$ susceptible restorer lines), respectively. Proportional contributions of restorer lines were greater than those of the CMS lines for leaf feeding, deadhearts, recovery and overall resistance, stalk
\end{abstract}

H. C. Sharma ( $\square)$ · M. K. Dhillon · G. Pampapathy · B. V. S. Reddy International Crops Research Institute for the SemiArid Tropics (ICRISAT), Patancheru, Hyderabad, Andhra Pradesh 502 324, India e-mail: h.sharma@cgiar.org length, nodes per plant, stem borer holes per plant, and peduncle tunneling. The general (GCA) and specific combining ability (SCA) estimates suggested that leaf feeding score, number of nodes, overall resistance score, panicle initiation, recovery score, and stalk length (dominance type of gene action) have been found to be associated with resistance to spotted stem borer, governed by additive type of gene action, their correlation and direct effects in the same direction, and explained $65.3 \%$ of the variation in deadhearts, and thus could be used as marker traits to select and breed for resistance to $C$. partellus in sorghum. The parents having significant SCA effects for two or more resistance traits for either or more parents have also been discussed for their use in the stem borer resistance breeding.

Keywords Stem borer . Chilo partellus . Sorghum bicolor . Cytoplasmic male-sterility . Mechanisms of resistance - Gene action

\section{Introduction}

Sorghum [Sorghum bicolor (L.) Moench] is one of the most important cereal crops in the semiarid tropics (SAT), and insect pests are the major yield-reducing factors. Sorghum is attacked by nearly 150 insect species, causing an annual loss of 
over $\$ 1$ billion in the SAT (ICRISAT 1992). A number of stem borers (Chilo partellus Swinhoe, Busseola fusca Fuller, Diatraea sp., Eldana saccharina Walker, Ostrinia nubilalis Hubner, and Sesamia sp.) have been reported as serious pests of sorghum, and constitute the most widely distributed and a devastating group of insect pests worldwide (Harris 1985). Of these, the spotted stem borer, C. partellus (Lepidoptera: Pyralidae) is the predominant species in Indian subcontinent, and South and eastern Africa, causing serious damage to sorghum, maize, and pearl millet (Ingram 1958; Jotwani and Young 1972; Singh and Rana 1989). It causes US\$ 334 million annual loss to sorghum alone in the SAT (ICRISAT 1992). It attacks sorghum from 2 weeks after germination until crop harvest and affects all plant parts except the roots. The first symptom of attack is the irregular shaped pinholes, caused by the early instar larvae feeding in the whorl, which later convert to elongated lesions on the leaves. The older larvae leave the whorl, bore into the stem and reach the growing point, where it cuts the growing point resulting in a characteristic "deadheart" symptom. In older plants, where internode elongation has started and the growing point has moved upwards, the larva feeds inside the stem, causing extensive tunneling. It also tunnels the peduncle and moves up the earhead. Feeding and stem tunneling by $C$. partellus larvae in sorghum results in crop losses as a consequence of reduction in foliage, destruction of the growing point, early leaf senescence, interference with translocation of metabolites and nutrients that result in under-development of the grain, stem breakage, reduced plant vigor, lodging, direct damage to panicles and loss in grain yield.

A number of genotypes with resistance to $C$. partellus have been identified, but the levels of resistance are low to moderate (Sharma et al. 2003). Most of the sources of resistance belong to durra group of sorghums of Indian origin followed by caudatum, conspicuum, caffrorum, dochna, roxburghii, cernuum, and nervosum-kaoling. Some of these sources are also resistant to other stem borer species infesting sorghum in Africa and Latin America (Reddy 1983). The discovery of cytoplasmic male-sterility (CMS)
(Stephens and Holland 1954) made it easier to incorporate desired traits into hybrids (House 1985). Because more than $75 \%$ of the area under sorghum in India is planted with high-yielding hybrids, which are based on milo cytoplasm, it is important to transfer genes conferring resistance to stem borer into cytoplasmic male-sterile $(A$ lines), maintainer ( $B$-lines), and restorer ( $R$-lines) lines to develop hybrids with high grain yield and resistance to this pest.

There is no information on the interaction between stem borer-resistant and -susceptible $A$-, $B$-, and $R$-lines relative to the expression and inheritance of resistance to $C$. partellus in $\mathrm{F}_{1}$ hybrids. Since future breeding efforts will largely focus on high-yielding stem borer-resistant hybrids, the present studies were carried out to understand the nature of gene action and the components that contribute to resistance or susceptibility to $C$. partellus. Such information will be useful in developing an appropriate strategy to produce stem borer-resistant hybrids for cultivation by the farmers in the semi-arid tropics.

\section{Materials and methods}

\section{Plant material}

The experiments were conducted at the International Crops Research Institute for the Semi-Arid Tropics (ICRISAT), Patancheru, Andhra Pradesh, India, during the 2003 and 2004 rainy (June-September) seasons. The experimental material consisted of $12 \mathrm{CMS}$ and maintainer lines, 12 restorer lines; and the $144 \mathrm{~F}_{1}$ hybrids. Details about the test material and their origin have earlier been reported in Dhillon et al. (2006). The experimental plots were given a basal dose of ammonium phosphate fertilizer@150 kg $\mathrm{ha}^{-1}$. Each entry was sown in 4 row plots of 2-m row length, and the rows were $75 \mathrm{~cm}$ apart. There were three replications in a randomized complete block design (RCBD). The seeds were sown with a 4-cone planter at a depth of $5 \mathrm{~cm}$ below the soil surface. The field was irrigated immediately after sowing, and the crop was maintained under rainfed conditions during the cropping season. One week after seedling emergence, thinning was 
carried out to maintain a spacing of $10 \mathrm{~cm}$ between the plants. No insecticide was applied in the experimental plots. Interculture and earthing up operations were carried out at 15 and 30 days after seedling emergence (DAE). Top dressing was done with urea @ $100 \mathrm{~kg} \mathrm{ha}^{-1}$ before earthing up at 30 DAE. Hand weeding was carried out as and when required.

\section{Insect infestation}

Natural infestation is confounded by oviposition preference and uneven distribution of the $C$. partellus within the field. Therefore, it is necessary to artificially infest the sorghum plants with C. partellus neonates to ensure that all plants being tested have an equal selection pressure. Thus, the test material was artificially infested with the laboratory-reared neonate larvae using a bazooka applicator (Taneja and Leuschner 1985a; Sharma et al. 1992). One day before infestation, the black-head stage egg masses containing paper strips were transferred from the refrigerator into plastic jars containing a carrier of $80 \mathrm{~g}$ of poppy (Papaver sp.) seed in the evening. On the subsequent morning, the freshly hatched neonate larvae were gently mixed with the carrier, and transferred into plastic bottles fixed to the bazooka applicator. In the field, the plants at 18 DAE were individually infested by placing the nozzle of the bazooka onto the leaf whorl. In each stroke, 5 to 7 larvae were released in the morning between $0800 \mathrm{~h}$ and $1100 \mathrm{~h}$ into the whorls of two rows in four row plots to cause an optimum level of leaf damage and deadheart formation.

\section{Observations}

The observations were recorded on plants with deadhearts, leaf feeding, leaf glossiness, panicle initiation, stalk length, nodes plant $^{-1}$, plant height, number of exit holes plant ${ }^{-1}$ caused by C. partellus, peduncle tunneling, recovery resistance, and overall resistance from the two stem borer infested rows. Data on numbers of plants with $C$. partellus deadhearts were recorded at 35 DAE, and expressed as percentage of the total number of plants. Leaf feeding by $C$. partellus larvae was assessed, two weeks after artificial infestation on a 1 to 9 rating scale $(1=$ no visible leaf injury or a small number of pin/shot hole type of injury on a few leaves, $2=$ small amount of shot hole type lesions on a few leaves, $3=$ shot hole injury common on several leaves, $4=$ several leaves with shot hole and elongated lesions, $5=$ several leaves with elongated lesions $(<2.5 \mathrm{~cm}), 6=$ several leaves with elongated lesions $(>2.5 \mathrm{~cm}), 7=$ long lesions common on about one-half of the leaves, $8=$ long lesions common on about two-third of the leaves, and $9=$ most leaves with long lesions) based on the type and amount of feeding (Sharma et al. 1992). Leaf glossiness was recorded at $5 \mathrm{DAE}$ on a scale of 1 to 5 [ 1 = highly glossy (light green, shining, narrow, and erect leaves), and $5=$ non-glossy (dark green, dull, broad, and drooping leaves) (Sharma and Nwanze 1997; Dhillon et al. 2005). Panicle initiation was recorded as number of days from germination to $50 \%$ of the plants showing panicle emergence. Stalk length was measured from five randomly selected plants per replication from the base of the plant to the last node from where panicle peduncle starts, and these plants were also counted for number of nodes, and the data was denoted as stalk length $(\mathrm{cm})$ and number of nodes plant ${ }^{-1}$. From the infested plots, five randomly selected plants were cut at the base before harvest, and exit hole counts were recorded per plant after removing the sheath leaves. The stems of five randomly selected plants were split open to determine the tunnel length plant $^{-1}(\mathrm{~cm})$ caused by $C$. partellus, and represented as tunneling percentage in relation to stem length. Plant height was recorded in $\mathrm{cm}$ from the five randomly selected plants per replication at maturity from the soil surface to the tip of the plant (including the panicle) in the uninfested plots. Recovery resistance was assessed on a scale of 1 to 9 ( $1=>80 \%$ plants with 2 to 3 uniform productive tillers; and $9=<20 \%$ damaged plants with 1 to 2 productive tillers) at maturity. The overall resistance score in the infested plots was evaluated visually on a 1 to 9 rating scale ( 1 = highly resistant, and $9=$ highly susceptible) by taking into account the leaf feeding, deadhearts, reduction in plant height, and productive tillers. 
Statistical analysis

The data were subjected to analysis of variance. The parents were classified as resistant and susceptible based on their reaction to $C$. partellus [resistant $=\leq R+X ;$ moderately resistant $=$ between $R+X+1$ and $\leq R+2 X$; and susceptible $=\geq R+2 X+1 \quad\{X=(A-R) / 3, \quad$ where $A=$ deadhearts (\%) in the susceptible check, and $R=$ deadhearts (\%) in the resistant check]. Genetic analyses were carried out via a line $\times$ tester method, as suggested by Kempthrone (1957), using GenStat Release 8.0. The sum of squares due to $F_{1}$ hybrids was partitioned into sum of squares due to females, males, and females $x$ males, which was used to estimate the additive and dominance components of the variation. Simple correlations, multiple regression, stepwise regression, and path coefficient analyses were carried out following the procedure of Dhillon et al. (2005), to understand the association between the morphological traits and resistance to $C$. partellus.

The main effects of CMS and restorer lines were equivalent to general combining ability (GCA), and the effects of a CMS line with a specific restorer were equivalent to specific combining ability (SCA) (Hallauer and Miranda 1981). Proportional contribution of females, males, and their interaction [contribution of females $=\{\mathrm{SS}$ (females) $/ \mathrm{SS}($ crosses $)\} \times 100$; contribution of males $=\{\mathrm{SS}$ (males) $/ \mathrm{SS}$ (crosses) $\}$ $\times 100$; contribution of females $\times$ males interaction $=\{$ SS $($ females $\times$ males $) /$ SS $($ crosses $) \times 100\}]$ to total variability of each trait/character was also computed.

\section{Results}

Feeding preference, deadheart formation, plant morphological traits, and recovery resistance

There were significant differences among different groups of parents and the hybrid combinations for stem borer leaf feeding, deadhearts, leaf glossiness, overall resistance, recovery resistance, stalk length, nodes per plant, holes per plant, and peduncle tunneling at $P=0.05$ (Table 1). The hybrids based on stem borer-resistant, moderately-resistant, or susceptible CMS and restorer lines were equally resistant or susceptible as the parents for leaf feeding (DR 5.8 to 6.6 vs. 5.9 to 6.6), except for the susceptible CMS and restorer lines (DR 7.1 to 7.4), which were more susceptible than the hybrids based on them or other hybrid combinations. There were no significant differences between stem borer-resistant and -moderately resistant group of CMS and restorer lines (DR 5.9 to 6.6) for leaf feeding score, but they had less leaf feeding than that on susceptible CMS and restorer (DR 7.1 to 7.4) group of genotypes. There was a significant and decreasing trend in deadheart formation by stem borer in the hybrids based on resistant CMS and restorer lines $<$ moderately resistant CMS and restorer lines $<$ susceptible CMS and restorer lines. The hybrids based on stem borer-resistant restorer lines with resistant, moderately resistant, or susceptible CMS lines had significantly less number of deadhearts than the hybrids based on other cross combinations, except for the hybrids based on resistant or moderately resistant CMS lines with moderately resistant restorers (Table 1). Irrespective of the cross combinations, hybrids had significantly less deadheart formation than those of susceptible CMS and restorer lines. The stem borer-resistant restorer lines had more leaf glossiness (2.2) than the other group of CMS and restorer lines, and the hybrid combinations (2.9 to 4.8) tended towards nonglossiness. Stem borerresistant CMS lines, moderately resistant restorers, and the hybrids based on resistant parents were equally glossy, and the hybrids based on resistant and moderately resistant CMS lines with resistant, moderately resistant or susceptible restorer lines had moderate level of leaf glossiness. However, the hybrids based on moderately resistant CMS and susceptible restorer lines, and susceptible CMS lines with resistant, moderately resistant and susceptible restorer lines were nonglossy. The resistant restorer lines had significantly higher overall and recovery resistance, which was on par with hybrids based on moderately resistant CMS and resistant restorer lines, and susceptible CMS and resistant restorer lines, as compared to other groups of restorer and CMS lines, and other hybrid combinations. 
Table 1 Mean performance of cytoplasmic male-sterile $(A)$ and restorer $(R)$ lines, and their $\mathrm{F}_{1}$ hybrids for resistance/ susceptibility to spotted stem borer, Chilo partellus in sorghum (ICRISAT, Patancheru, India 2003-2004)

\begin{tabular}{|c|c|c|c|c|c|c|c|c|c|}
\hline Groups & $\begin{array}{l}\text { Leaf } \\
\text { feeding } \\
\text { score }^{\mathrm{a}} \\
(1-9)\end{array}$ & $\begin{array}{l}\text { Deadhearts } \\
(\%)\end{array}$ & $\begin{array}{l}\text { Leaf } \\
\text { glossiness }{ }^{\mathrm{b}} \\
(1-5)\end{array}$ & $\begin{array}{l}\text { Overall } \\
\text { resistance } \\
\text { score }^{c}(1-9)\end{array}$ & $\begin{array}{l}\text { Recovery } \\
\text { score }^{\mathrm{d}} \\
(1-9)\end{array}$ & $\begin{array}{l}\text { Stalk } \\
\text { length } \\
(\mathrm{cm})\end{array}$ & $\begin{array}{l}\text { Nodes } \\
\text { plant }^{-1} \\
\text { (no.) }\end{array}$ & $\begin{array}{l}\text { Exit } \\
\text { holes } \\
\text { plant }^{-1} \\
\text { (no.) }\end{array}$ & $\begin{array}{l}\text { Peduncle } \\
\text { tunneling } \\
(\%)\end{array}$ \\
\hline \multicolumn{10}{|c|}{ Hybrid combinations } \\
\hline $\mathrm{RA} \times \mathrm{RR}$ & 5.9 & 19.6 & 2.9 & 6.3 & 5.8 & 119.8 & 10.1 & 4.1 & 4.9 \\
\hline $\mathrm{RA} \times \mathrm{MRR}$ & 5.8 & 25.4 & 3.2 & 7.0 & 6.3 & 79.9 & 9.5 & 3.9 & 10.9 \\
\hline $\mathrm{MRA} \times \mathrm{RR}$ & 6.1 & 17.6 & 3.6 & 5.8 & 5.1 & 144.3 & 10.6 & 5.8 & 6.8 \\
\hline $\begin{array}{r}\text { MRA } \times \\
\text { MRR }\end{array}$ & 6.2 & 29.1 & 3.9 & 7.1 & 6.2 & 90.9 & 9.6 & 4.8 & 10.8 \\
\hline $\mathrm{RA} \times \mathrm{SR}$ & 6.3 & 38.7 & 3.8 & 7.4 & 6.9 & 83.6 & 9.2 & 4.6 & 19.4 \\
\hline $\mathrm{MRA} \times \mathrm{SR}$ & 6.5 & 37.1 & 4.4 & 7.3 & 6.4 & 89.9 & 9.3 & 4.7 & 9.9 \\
\hline $\mathrm{SA} \times \mathrm{RR}$ & 6.3 & 19.6 & 4.2 & 5.4 & 4.8 & 141.2 & 10.5 & 6.8 & 18.8 \\
\hline $\mathrm{SA} \times \mathrm{MRR}$ & 6.6 & 37.4 & 4.2 & 7.0 & 5.8 & 83.7 & 9.1 & 4.9 & 13.5 \\
\hline $\mathrm{SA} \times \mathrm{SR}$ & 6.1 & 36.2 & 4.6 & 6.3 & 5.8 & 102.0 & 9.7 & 5.4 & 11.5 \\
\hline \multicolumn{10}{|l|}{ Parents } \\
\hline RA & 6.0 & 23.9 & 3.3 & 7.3 & 6.9 & 67.3 & 9.3 & 2.9 & 6.1 \\
\hline $\mathrm{RR}$ & 5.9 & 14.8 & 2.2 & 6.0 & 5.5 & 136.9 & 11.4 & 4.0 & 9.2 \\
\hline MRA & 6.6 & 39.6 & 3.7 & 8.0 & 7.2 & 70.4 & 9.0 & 4.1 & 14.0 \\
\hline MRR & 6.3 & 43.3 & 2.9 & 7.3 & 6.0 & 89.4 & 10.0 & 3.3 & 12.1 \\
\hline SA & 7.4 & 70.9 & 4.8 & 7.8 & 5.8 & 53.9 & 9.1 & 5.7 & 12.9 \\
\hline SR & 7.1 & 67.1 & 4.2 & 7.5 & 6.8 & 85.1 & 8.3 & 3.4 & 11.1 \\
\hline $\begin{array}{l}\text { LSD } \\
(P=0.05)\end{array}$ & 0.58 & 11.66 & 0.40 & 0.68 & 0.71 & 16.13 & 0.69 & 2.05 & 8.16 \\
\hline
\end{tabular}

$\mathrm{RA}=$ Resistant $A$-lines, $\mathrm{RR}=$ Resistant $R$-lines, $\mathrm{MRA}=$ Moderately resistant A-lines, MRR $=$ Moderately resistant $R$ lines, $\mathrm{SA}=$ Susceptible $A$-lines, $\mathrm{SR}=$ Susceptible $R$-lines

${ }^{\text {a }}$ Leaf feeding score $(1 \leq 10 \%$, and $9 \geq 80 \%$ leaf area damaged)

${ }^{\mathrm{b}}$ Leaf glossiness $(1=$ leaves light yellow shining and eract, and $5=$ leaves dull green, non-shiny and dropping)

${ }^{\text {c }}$ Overall resistance score $(1 \leq 10 \%$ plants with deadhearts, and $>80 \%$ of the damaged plants with $2-3$ uniform tillers, and $9 \geq 80 \%$ plants with deadhearts, and $<20 \%$ plants with $2-3$ uniform tillers)

${ }^{d}$ Recovery score ( $1 \geq 80 \%$ damaged plants with $2-3$ uniform tillers, and $9 \leq 20 \%$ plants with $2-3$ uniform tillers)

The resistant restorer lines, and the hybrids based on them had significantly longer stalk length and number of nodes (including moderately resistant restorer lines for number of nodes) as compared to other groups of CMS and restorer lines, and the hybrids. All the parents (except susceptible CMS lines), hybrids based on resistant CMS with resistant, moderately resistant, or susceptible restorer lines, and the hybrids based on moderately resistant CMS and moderately resistant or susceptible restorer lines had comparatively less number of holes by spotted stem borer than that in other hybrid combinations. The peduncles of hybrids based on resistant CMS and susceptible restorer lines, and susceptible CMS and resistant restorer lines had comparatively more tunneling by the stem borer than the other parents and the hybrids based on other combinations.
Association of plant morphological traits with resistance to $C$. partellus

Resistance to spotted stem borer (in terms of leaf feeding, deadhearts, overall resistance, and recovery resistance) was positively correlated with leaf glossiness, and negatively with number of nodes plant $^{-1}$ and stalk length (Table 2). Stem tunneling was positively correlated with overall and recovery resistance scores. Days to panicle initiation were positively associated with deadhearts and plant height, but negatively associated with recovery resistance and agronomic scores (Table 2). Leaf feeding scores were positively associated with deadhearts, recovery, and overall resistance scores. The plant traits having significant correlation with spotted stem borer damage were used for regression and path coefficient 
Table 2 Association of plant morphological traits with resistance/susceptibility to spotted stem borer, Chilo partellus in sorghum (ICRISAT, Patancheru, India 2003-2004)

\begin{tabular}{|c|c|c|c|c|}
\hline Traits & Deadhearts (\%) & $\begin{array}{l}\text { Leaf feeding } \\
\text { score }(1-9)\end{array}$ & $\begin{array}{l}\text { Recovery } \\
\text { score (1-9) }\end{array}$ & $\begin{array}{l}\text { Overall resistance } \\
\text { score }(1-9)\end{array}$ \\
\hline Leaf feeding score (lfs) & 0.63 & 1.00 & 0.24 & 0.37 \\
\hline Leaf glossiness (gs) & 0.23 & 0.31 & 0.18 & 0.18 \\
\hline Number of holes per plant $(h)$ & -0.32 & -0.03 & -0.27 & -0.30 \\
\hline Number of nodes per plant $(n)$ & -0.49 & -0.26 & -0.54 & -0.53 \\
\hline Number of larvae/pupae per plant (lp) & -0.08 & 0.14 & -0.15 & -0.12 \\
\hline Peduncle length & 0.03 & 0.04 & -0.04 & 0.05 \\
\hline Peduncle tunneling (pt) & 0.30 & 0.27 & 0.27 & 0.27 \\
\hline Stalk length (sl) & -0.55 & -0.22 & -0.70 & -0.74 \\
\hline Stem tunneling & 0.08 & 0.05 & 0.20 & 0.22 \\
\hline Panicle exersion & -0.07 & -0.01 & -0.13 & -0.04 \\
\hline Panicle initiation (pi) & 0.18 & 0.13 & -0.20 & -0.13 \\
\hline Plant height infested & -0.52 & -0.22 & -0.76 & -0.77 \\
\hline Plant height uninfested (phui) & -0.51 & -0.17 & -0.73 & -0.74 \\
\hline Agronomic score (as) & -0.29 & -0.17 & -0.26 & -0.34 \\
\hline
\end{tabular}

Correlation coefficients $(r)$ exceeding 0.18 and 0.21 (irrespective of sign) are significant at $P=0.05$ and 0.01 , respectively

analysis. Leaf feeding score, leaf glossiness, exit holes plant $^{-1}$, larvae/pupae plant $^{-1}$, number of nodes plant ${ }^{-1}$, days to panicle initiation, peduncle tunneling, plant height of uninfested plants, stalk length, overall resistance score, recovery resistance score, and agronomic score explained $65.1 \%$ of the total variation in stem borer deadhearts. Stepwise regression analyses indicated that leaf feeding score, number of nodes, overall resistance score, days to panicle initiation, recovery resistance score, and stalk length explained $65.3 \%$ of the variation for stem borer deadhearts.

Since, resistance to stem borer is a complex phenomenon, and a number of componential traits are confounded to explain resistance to this pest. However, the path coefficient analysis indicated that leaf feeding score, leaf glossiness, peduncle tunneling, number of stem borer holes plant $^{-1}$, overall resistance score, stalk length, number of nodes plant ${ }^{-1}$, height of uninfested plants, and days to panicle initiation had the correlation and direct effects in the same direction for stem borer deadhearts, and hence, these can be used to select for resistance to stem borer (Table 3). The indirect effects of leaf glossiness, peduncle tunneling, and number of nodes plant ${ }^{-1}$ on stem borer deadheart formation were largely through overall resistance and leaf feeding scores. However, the indirect effects of number of exit holes plant $^{-1}$, stalk length, and plant height of uninfested plants were through overall resistance score, and number of nodes plant ${ }^{-1}$, and days to panicle initiation through leaf feeding and recovery resistance scores (Table 3).

General combining ability (GCA) effects

\section{Leaf feeding and deadhearts}

The mean squares for hybrids, CMS lines, restorer lines, and for their interactions with the environments were statistically significant at $P=0.05$ for leaf feeding and deadhearts by spotted stem borer, except in case of environments $\times$ hybrids, and environments $\times$ restorer lines for deadhearts (Table 4). The proportional contribution of restorer lines was greater than that of the CMS lines on leaf feeding and deadheart formation by $C$. partellus (Table 4). The GCA effects for leaf feeding and deadhearts for CMS lines SP 55301A, CK 60A, and Tx 623A (except for leaf feeding) were significant and negative, whereas such effects for ICSA 42A were significant and positive (Table 5). However, the GCA effects for leaf feeding and deadhearts for restorer lines ICSV 700, ICSV 708, IS 18551, SFCR 125, and Swarna were significant and negative (except ICSV 700 for leaf feeding and SFCR 125 for deadhearts), while such effects for 
Table 3 Path coefficients analysis for stem borer damage parameters and plant morphological traits associated with resistance to spotted stem borer, Chilo partellus in sorghum (ICRISAT, Patancheru, India 2003-2004)

\begin{tabular}{|c|c|c|c|c|c|c|c|c|c|c|c|c|}
\hline Traits & lfs & gs & $\mathrm{pt}$ & As & $h$ & ors & rs & sl & $n$ & phui & pi & $r$ \\
\hline feeding & 037 & 0.02 & 02 & 0 & 00 & 0.15 & -0.06 & 0 & 0.06 & 1 & 0.03 & 0.63 \\
\hline Leaf glossiness score (gs) & 0.12 & 0.07 & 0.00 & 0.00 & -0.01 & 0.08 & 0.04 & 0.03 & 0.06 & 0.01 & -0.08 & 0.23 \\
\hline Peduncle tunneling (pt) & 0.10 & 0.00 & & 0.00 & 0.00 & 0. & 7 & 0 & 0.03 & 1 & 0 & 0.30 \\
\hline Agronomic score (as) & -0.06 & -0.02 & -0.01 & 0.00 & -0.01 & -0.14 & 0.06 & -0.06 & -0.06 & -0.03 & 0.05 & -0.29 \\
\hline Exit holes plant $^{-1}(h)$ & -0.01 & 0.01 & 0.01 & 0.00 & -0.05 & -0.12 & 0.07 & -0.04 & -0.07 & -0.03 & -0.06 & -0.32 \\
\hline Overall $\mathrm{r}$ & 0. & 0.01 & & 0.00 & 0. & 0. & -0 . & 0 . & 0.11 & 0 . & -0 & 0.60 \\
\hline (rs) & 0.09 & 0.01 & 0.02 & 0.00 & 0.01 & 0.37 & -0 & 0.08 & 0.11 & 0.05 & -0.05 & 0.45 \\
\hline Stalk length (sl) & -0.08 & -0.02 & -0.02 & 0.00 & -0.02 & -0.31 & 0.17 & $-\mathbf{0 . 1 1}$ & -0.16 & -0.07 & 0.06 & -0.55 \\
\hline Number of nodes plar & -0.10 & -0.02 & -0.01 & 0.00 & -0.02 & -0.22 & 0.13 & -0.08 & -0.21 & -0.05 & 0.08 & -0.49 \\
\hline Plant height uninfested (phui) & -0.06 & -0.01 & -0.01 & 0.00 & -0.02 & -0.31 & 0.18 & -0.10 & -0.13 & -0.07 & 0.04 & -0.51 \\
\hline Panicle initiation (pi) & 0.04 & -0.02 & 0.01 & 0.00 & 0.01 & -0.05 & 0.05 & -0.03 & -0.07 & -0.01 & 0.25 & 0.18 \\
\hline
\end{tabular}

The diagonal values in bold are the direct effects and rest of the values are indirect effects on independent variables on the stem borer deadheart formation. Correlation coefficients $(r)$ exceeding 0.18 and 0.21 (irrespective of sign) are significant at $P=0.05$ and 0.01 , respectively

Table 4 Mean squares for damage by spotted stem borer, Chilo partellus, and plant morphological traits in $\mathrm{F}_{1}$ sorghum hybrids and their parents (ICRISAT, Patancheru, India 2003-2004)

\begin{tabular}{|c|c|c|c|c|c|c|c|c|c|c|}
\hline $\begin{array}{l}\text { Source of } \\
\text { variation }\end{array}$ & df & $\begin{array}{l}\text { Leaf } \\
\text { feeding } \\
\text { score } \\
(1-9)\end{array}$ & $\begin{array}{l}\text { Deadhearts } \\
(\%)\end{array}$ & $\begin{array}{l}\text { Leaf } \\
\text { glossiness } \\
(1-5)\end{array}$ & $\begin{array}{l}\text { Overall } \\
\text { resistance } \\
\text { score }(1-9)\end{array}$ & $\begin{array}{l}\text { Recovery } \\
\text { score } \\
(1-9)\end{array}$ & $\begin{array}{l}\text { Stalk } \\
\text { length } \\
(\mathrm{cm})\end{array}$ & $\begin{array}{l}\text { Nodes } \\
\text { plant }^{-1} \\
\text { (no.) }\end{array}$ & $\begin{array}{l}\text { Exit } \\
\text { holes } \\
\text { plant }^{-1} \\
\text { (no.) }\end{array}$ & $\begin{array}{l}\text { Peduncle } \\
\text { tunneling } \\
(\%)\end{array}$ \\
\hline Environments & 1 & 7.5 & 412.3 & 5.90 & 2.3 & 1.0 & $50814.8^{*}$ & $328.6^{*}$ & $646.4^{*}$ & $1901.2^{* *}$ \\
\hline Hybrids & 143 & 1.7 & $893.2^{* *}$ & $4.0^{* *}$ & $5.5^{* *}$ & $5.2^{* *}$ & $6766.2^{* *}$ & $5.3^{* *}$ & $16.4^{* *}$ & $328.0^{* *}$ \\
\hline $\begin{array}{l}\text { Environments } \times \\
\text { hybrids }\end{array}$ & 141 & $1.0^{*}$ & 309.0 & 0.80 & $1.2^{* *}$ & 1.1 & $1159.3^{* *}$ & $1.8^{* *}$ & $10.8^{* * *}$ & $264.9^{* *}$ \\
\hline CMS & 11 & $4.5^{* *}$ & $1702.3^{* *}$ & $1241.0^{* *}$ & $3.4^{* *}$ & $6.4^{* *}$ & $5773.4^{* *}$ & $14.7^{* *}$ & $29.1^{* *}$ & $538.7^{* *}$ \\
\hline Restorer & 11 & $7.6^{* *}$ & $6160.8^{* *}$ & $22.8^{* *}$ & $48.6^{* * *}$ & $43.3^{* *}$ & $67394.6^{* *}$ & $32.2^{* *}$ & $55.1^{* *}$ & $675.1^{* * *}$ \\
\hline $\begin{array}{l}\text { Environments } \times \\
\text { CMS }\end{array}$ & 11 & $1.8^{* *}$ & $797.6^{* *}$ & $3.3^{* *}$ & $2.9^{* *}$ & $2.4^{* *}$ & $1218.3^{* *}$ & $5.8^{* *}$ & 8.1 & $345.5^{*}$ \\
\hline $\begin{array}{l}\text { Environments } \times \\
\text { restorer }\end{array}$ & 11 & $1.8^{* *}$ & 441.3 & $2.5^{* *}$ & $2.9^{* *}$ & $2.0^{*}$ & $3513.6^{* *}$ & $1.5^{*}$ & 3.9 & $303.0^{*}$ \\
\hline $\mathrm{CMS} \times$ restorer & 121 & 0.9 & 337.2 & $1.0^{* *}$ & $1.8^{* * *}$ & $1.7^{* *}$ & $1323.9^{* *}$ & $2.0^{* *}$ & $11.7^{* *}$ & $275.9^{* *}$ \\
\hline $\begin{array}{l}\text { Environments } \times \\
\text { CMS } \times \text { restorer }\end{array}$ & 119 & 0.8 & 255.5 & $0.4^{* *}$ & 0.9 & 0.9 & $938.9^{* *}$ & 1.4 & $11.7^{* *}$ & $254.0^{* *}$ \\
\hline Error & 568 & 0.8 & 289.8 & 0.3 & 0.9 & 0.9 & 534.4 & 1.2 & 6.2 & 163.0 \\
\hline \multicolumn{11}{|c|}{ Proportional contribution to total variance (\%) } \\
\hline Females & & 21.2 & 14.7 & 44.1 & 4.8 & 9.5 & 6.6 & 21.2 & 13.7 & 12.7 \\
\hline Males & & 35.2 & 53.2 & 34.6 & 68.0 & 63.5 & 76.8 & 46.6 & 25.9 & 15.9 \\
\hline Females $\times$ males & & 43.6 & 32.1 & 21.3 & 27.2 & 27.0 & 16.6 & 32.1 & 60.5 & 71.4 \\
\hline
\end{tabular}

\footnotetext{
* $F$-test significant at $P=0.05$

** $\quad F$-test significant at $P=0.01$
}

ICSV 91011, CS 3541, MR 750, and ICSV 745 were significant and positive (except ICSV 745 for deadhearts) (Table 5). The estimates of additive variances for leaf feeding and deadheart were greater than their dominance variances (Table 6) suggesting the role of additive type of gene action conditioning these traits.

Recovery resistance 
Table 5 General combining ability (GCA) effects of CMS and restorer lines of sorghum for stem borer damage and morphological traits associated with resistance to Chilo partellus (ICRISAT, Patancheru, India 2003-2004)

\begin{tabular}{|c|c|c|c|c|c|c|c|c|c|}
\hline Genotypes & $\begin{array}{l}\text { Leaf } \\
\text { feeding } \\
\text { score }(1-9)\end{array}$ & $\begin{array}{l}\text { Deadhearts } \\
(\%)\end{array}$ & $\begin{array}{l}\text { Leaf } \\
\text { glossiness } \\
(1-5)\end{array}$ & $\begin{array}{l}\text { Overall } \\
\text { resistance } \\
\text { score (1-9) }\end{array}$ & $\begin{array}{l}\text { Recovery } \\
\text { score } \\
(1-9)\end{array}$ & $\begin{array}{l}\text { Stalk } \\
\text { length } \\
(\mathrm{cm})\end{array}$ & $\begin{array}{l}\text { Nodes } \\
\text { plant }^{-1} \\
\text { (no.) }\end{array}$ & $\begin{array}{l}\text { Exit holes } \\
\text { plant }^{-1} \\
\text { (no.) }\end{array}$ & $\begin{array}{l}\text { Peduncle } \\
\text { tunneling } \\
(\%)\end{array}$ \\
\hline \multicolumn{10}{|l|}{ CMS lines } \\
\hline $\begin{array}{l}\text { SPSFR } \\
94011 \mathrm{~A}\end{array}$ & -0.15 & 0.55 & $-0.38^{* *}$ & $0.27^{*}$ & -0.01 & $11.47^{* *}$ & $0.65^{* *}$ & -0.23 & -1.17 \\
\hline $\begin{array}{l}\text { SPSFR } \\
94012 \mathrm{~A}\end{array}$ & 0.23 & -2.98 & $0.64^{* *}$ & -0.06 & 0.03 & $7.25^{* *}$ & 0.07 & 0.51 & -2.15 \\
\hline $\begin{array}{l}\text { SPSFR } \\
94006 \mathrm{~A}\end{array}$ & -0.02 & 1.75 & $-0.40^{* *}$ & 0.14 & 0.05 & -1.82 & -0.07 & $-0.60^{*}$ & -0.35 \\
\hline $\begin{array}{l}\text { SPSFR } \\
94007 \mathrm{~A}\end{array}$ & 0.12 & 1.26 & $-0.33^{* *}$ & -0.07 & -0.11 & $6.26^{*}$ & 0.25 & -0.22 & 2.29 \\
\hline $\begin{array}{l}\text { SPSFR } \\
94010 \mathrm{~A}\end{array}$ & 0.08 & 3.46 & $-0.33^{* *}$ & 0.19 & $0.28^{*}$ & 3.46 & -0.06 & $0.58^{*}$ & 1.63 \\
\hline $\begin{array}{l}\text { SPSFR } \\
94034 \mathrm{~A}\end{array}$ & 0.16 & 2.03 & $-0.54^{* *}$ & $0.32^{* *}$ & $0.30^{* *}$ & $5.58^{*}$ & $0.59^{* *}$ & $-0.66^{*}$ & -1.93 \\
\hline SP 55299A & 0.16 & 1.15 & $-0.21^{* *}$ & -0.02 & $-0.23^{*}$ & 2.73 & $0.27^{*}$ & 0.08 & 1.29 \\
\hline SP 55301A & $-0.58^{* *}$ & $-5.46^{* *}$ & $-0.82^{* *}$ & -0.10 & $0.52^{* *}$ & $-18.74^{* *}$ & -0.23 & $-1.04^{* *}$ & 0.21 \\
\hline $296 \mathrm{~A}$ & 0.19 & 3.22 & $0.43^{* *}$ & $-0.46^{* *}$ & $-0.56^{* *}$ & -1.11 & -0.18 & $0.68^{*}$ & -1.10 \\
\hline Tx 623A & -0.10 & $-5.51^{* *}$ & $0.47^{* *}$ & 0.08 & 0.19 & 4.14 & $-0.39^{* *}$ & $0.83^{* *}$ & 0.84 \\
\hline CK 60A & $-0.34^{* *}$ & $-8.63^{* *}$ & $0.56^{* *}$ & $-0.24^{*}$ & -0.12 & $-14.66^{* *}$ & $-1.03^{* *}$ & $0.63^{*}$ & 1.95 \\
\hline ICSA 42A & $0.24^{*}$ & $9.16^{* *}$ & $0.91^{* *}$ & -0.04 & $-0.33^{* *}$ & -4.55 & 0.12 & -0.56 & -1.52 \\
\hline $\mathrm{SE} \pm(\mathrm{GCA})$ & 0.10 & 2.01 & 0.06 & 0.11 & 0.11 & 2.72 & 0.13 & 0.29 & 1.34 \\
\hline $\mathrm{SE} \pm(\mathrm{gi}-\mathrm{gj})$ & 0.14 & 2.84 & 0.09 & 0.15 & 0.16 & 3.85 & 0.19 & 0.42 & 1.90 \\
\hline \multicolumn{10}{|l|}{ Restorer lines } \\
\hline ICSV 705 & -0.17 & 2.07 & $-0.33^{* *}$ & $0.91^{* *}$ & $0.99^{* *}$ & $-33.12^{* *}$ & $-0.59^{* *}$ & -0.45 & $5.10^{* *}$ \\
\hline ICSV 700 & -0.15 & $-14.87^{* *}$ & $-0.44^{* *}$ & $-1.75^{* *}$ & $-1.72^{* *}$ & $67.14^{* *}$ & $1.44^{* *}$ & $0.87^{* *}$ & $-4.71^{* *}$ \\
\hline ICSV 708 & $-0.50^{* *}$ & $-4.98^{*}$ & $-0.64^{* *}$ & 0.11 & -0.06 & $-6.96^{*}$ & $-0.27^{*}$ & -0.17 & -0.54 \\
\hline PS 30710 & -0.12 & -0.50 & $-0.38^{* *}$ & $-0.21^{* *}$ & $-0.37^{* *}$ & $-12.56^{* *}$ & $-0.38^{* *}$ & $-0.97^{* *}$ & -1.34 \\
\hline IS 18551 & $-0.24^{*}$ & $-12.30^{* *}$ & $-0.45^{* *}$ & $-1.46^{* *}$ & $-1.13^{* *}$ & $51.48^{* *}$ & $0.86^{* * *}$ & $1.84^{*}$ & -1.50 \\
\hline SFCR 151 & 0.06 & -1.08 & $0.19^{* *}$ & $0.51^{* *}$ & $0.41^{* *}$ & $-7.93^{* *}$ & -0.11 & $-1.04^{* *}$ & -1.72 \\
\hline SFCR 125 & $-0.24^{*}$ & -3.45 & $-0.44^{* *}$ & -0.16 & -0.16 & $15.44^{* *}$ & $0.54^{* * *}$ & -0.18 & -1.04 \\
\hline ICSV 91011 & $0.42^{* *}$ & $8.00^{* *}$ & $0.17^{* *}$ & 0.19 & 0.17 & $-7.47^{* *}$ & -0.10 & 0.43 & $3.20^{*}$ \\
\hline CS 3541 & $0.46^{* *}$ & $9.87^{* *}$ & $0.51^{* *}$ & $0.48^{* *}$ & $0.48^{* *}$ & $-25.23^{* *}$ & $-0.57^{* *}$ & $-0.74^{*}$ & -1.28 \\
\hline MR 750 & $0.42^{* *}$ & $18.40^{* *}$ & $0.38^{* *}$ & $0.80^{* *}$ & $0.77^{* *}$ & $-18.56^{* *}$ & $-0.94^{* *}$ & $-0.77^{* *}$ & 0.76 \\
\hline ICSV 745 & $0.30^{* *}$ & 3.00 & $0.68^{* *}$ & $0.22^{*}$ & $0.39^{* *}$ & 0.07 & 0.14 & 0.56 & -1.69 \\
\hline Swarna & $-0.25^{*}$ & $-4.16^{*}$ & $0.74^{* *}$ & $0.34^{* *}$ & $0.23^{*}$ & $-22.30^{* *}$ & -0.01 & 0.60 & $4.77^{* * *}$ \\
\hline $\mathrm{SE} \pm(\mathrm{GCA})$ & 0.10 & 2.01 & 0.06 & 0.11 & 0.11 & 2.72 & 0.13 & 0.29 & 1.34 \\
\hline $\mathrm{SE} \pm(\mathrm{gi}-\mathrm{gj})$ & 0.14 & 2.84 & 0.09 & 0.15 & 0.16 & 3.85 & 0.19 & 0.42 & 1.90 \\
\hline
\end{tabular}

\footnotetext{
* GCA effects significant at $P=0.01$

** GCA effects significant at $P=0.05$
}

The mean squares for overall and recovery resistance for hybrids, CMS lines, restorer lines, and their interaction with environments, and $\mathrm{CMS} \times$ restorer were significant at $P=0.05$ (except environments $\times$ hybrids for recovery resistance) (Table 4). The proportional contribution of restorer lines was more than that of the CMS lines for overall and recovery resistance scores. The GCA effects for overall resistance score of the CMS lines 296 and CK 60, and of SP 55299, 296, and ICSA 42 for recovery resistance score were significant and negative; whereas such effects of CMS lines SPSFR 94011 and SPSFR 94034 for overall resistance score, and of SPSFR 94010, SPSFR 94034, and SP 55301 for recovery resistance score were significant and positive (Table 5). The GCA effects for overall and recovery resistance scores for the restorers ICSV 700, PS 30710, and IS 18551 were significant and negative, whereas such effects for ICSV 705 , SFCR 151, CS 3541, MR 750, ICSV 745, and Swarna were significant and positive. The results 
Table 6 Nature of gene action for stem borer damage in sorghum, and the morphological traits associated with resistance to spotted stem borer, Chilo partellus (ICRISAT, Patancheru, India 2003-2004)

\begin{tabular}{lccc}
\hline Traits & \multicolumn{2}{c}{ Genotypic variance } & Gene action \\
\cline { 2 - 3 } & \multicolumn{2}{c}{$\sigma^{2} \mathrm{~A}$} & \multicolumn{2}{c}{$\sigma^{2} \mathrm{D}$} & \\
\hline Leaf feeding score (1-9) & $0.14^{* *}$ & 0.02 & Additive \\
Deadhearts (\%) & $31.53^{* *}$ & 7.89 & Additive \\
Leaf glossiness (1-5) & $0.54^{* *}$ & $0.12^{* *}$ & Additive + Dominance \\
Overall resistance score (1-9) & $0.84^{* *}$ & $0.15^{* *}$ & Additive + Dominance \\
Recovery score (1-9) & $1.77^{* *}$ & $0.13^{* * *}$ & Additive + Dominance \\
Stalk length (cm) & $42.81^{* *}$ & $131.57^{* *}$ & Additive + Dominance \\
Nodes plant ${ }^{-1}$ (no.) & $2.06^{* *}$ & $0.13^{* *}$ & Additive + Dominance \\
Exit holes plant ${ }^{-1}$ (no.) & $4.62^{* *}$ & $0.91^{* *}$ & Additive + Dominance \\
Stalk tunneling (\%) & 21.11 & $4.69^{* *}$ & Dominance \\
\hline
\end{tabular}

\footnotetext{
* Significant at $P=0.05$

** Significant at $P=0.01$
}

suggested that additive and dominance type of gene action controls the expression of these traits.

GCA effects for morphological traits associated with resistance to Chilo partellus

The mean squares for hybrids, CMS lines, restorer lines, and CMS $\times$ restorer, and for their interactions with the environments (except for hybrids) for leaf glossiness were significant at $P=0.05$ (Table 4). The proportional contribution of CMS lines was more than that of the restorer lines for leaf glossiness. The GCA effects for leaf glossiness of glossy CMS and restorer lines were significant and negative (except in case of SFCR 151), while for those of nonglossy CMS and restorer lines were significant and positive (Table 5).

The mean squares for hybrids, CMS lines, restorer lines, and CMS $\times$ restorer, and for their interactions with the environments were significant at $P=0.05$ for stalk length, nodes plant $^{-1}$ (except for environment $\times \mathrm{CMS} \times$ restorer), exit holes plant $^{-1}$ (except for $\mathrm{CMS} \times$ environment, and restorer $\times$ environment), and peduncle tunneling (Table 4). The proportional contribution of restorer lines was more than that of the CMS lines for stalk length, nodes plant ${ }^{-1}$, exit holes plant $^{-1}$, and peduncle tunneling. The GCA effects for stalk length of CMS lines SP 55301 and CK 60; and the restorer lines ICSV 705, PS 30710, SFCR 151, ICSV 91011, CS 3541, MR 750, and Swarna were significant and negative, while for those of CMS lines SPSFR 91011, SPSFR 91012, SPSFR 94007, and SPSFR 94034; and restorer lines ICSV 700, IS 18551, and SFCR 125 were significant and positive (Table 5). The GCA effects for number of nodes in CMS lines Tx 623 and CK 60, and restorer lines ICSV 705, ICSV 708, PS 30710, CS 3541, and MR 750 were significant and negative, while for those of CMS lines SPSFR 94034 and SP 55299, and restorer lines ICSV 700, IS 18551, and SFCR 125 were significant and positive (Table 5). The GCA effects for number of exit holes in CMS lines SPSFR 94006, SPSFR 94034, and SP 55301, and restorer lines PS 30710, SFCR 151, CS 3541, and MR 750 were significant and negative, while for those of CMS lines SPSFR 94010, 296, Tx 623, and CK 60; and the restorer ICSV 700 were significant and positive (Table 5). The GCA effects for peduncle tunneling in the restorer line, ICSV 700 were significant and negative, while for those of ICSV 705, ICSV 91011, and Swarna were significant and positive (Table 5). The estimates of additive variances for leaf glossiness, nodes plant $^{-1}$, and exit holes plant ${ }^{-1}$, were greater than their dominance variances (Table 6), suggesting the role of additive and dominance type of gene action conditioning these traits.

Specific combining ability (SCA) effects

The SCA effects of SPSFR $94006 \times$ PS 30710 for leaf feeding, overall and recovery resistance, SPSFR $94010 \times$ ICSV 91011 for leaf feeding and 
stalk length, SPSFR $94011 \times$ ICSV 700 for overall resistance score, number of nodes and exit holes by stem borer, and leaf glossiness, SPSFR $94011 \times$ IS 18551 for overall resistance and stalk length, and SPSFR $94012 \times$ ICSV 91011, SP $55299 \times$ ICSV 91011, SP $55301 \times$ ICSV 705 (including for peduncle tunneling), and SP $55301 \times$ ICSV 708 (including for stalk length) for overall and recovery resistance scores were significant at $P=0.05$. The SCA effects of SP $55301 \times$ CS 3541 for stalk length and peduncle length, ICSA $42 \times$ ICSV 745 and SPSFR $94006 \times$ SFCR 151 (except for leaf glossiness and peduncle tunneling) for peduncle length, peduncle tunneling, leaf glossiness, and number of nodes plant ${ }^{-1}$, SP $55299 \times$ IS 18551 for overall resistance and stalk length, and $296 \times$ IS 18551 for overall resistance and stalk length were also significant at $P=0.05$. Among the restorers, CS 3541 was good specific combiner with CMS lines CK 60, ICSA 42, 296, and SPSFR 94006 for leaf feeding, overall resistance, peduncle length, and peduncle tunneling, respectively. However, ICSV 745 had good specific combining ability with CMS lines Tx 623, SP 55299, and SPSFR 94034 for number of stem borer holes plant ${ }^{-1}$. The parents having significant and good SCA effects for two or more resistance traits could either be used in the stem borer resistance breeding or per se cultivation by the farmers.

\section{Discussion}

A number of factors have earlier been reported to be associated with resistance to spotted stem borer in sorghum such as-erectness of leaves and orientation of the leaf hairs, tightness of the leaf sheath and midrib, diameter of the leaf whorl, and large internode length (Woodhead and Taneja 1987; Taneja and Woodhead 1989; Kishore 1991a), which influence the dispersal of neonate larvae resulting in low deadheart formation. The larval duration on the sorghum stem has been reported to be positively correlated with plant height and nodes plant ${ }^{-1}$, but negatively correlated with peduncle length (Singh and Rana 1984). Early panicle initiation and rapid internode elongation (Taneja and Woodhead 1989), and stem tunneling (Kishore 1991b) have earlier been reported to be the major plant characters associated with resistance to stem borer. Stem tunneling rather than leaf feeding and deadhearts is the primary cause of yield loss (Alghali 1986). However, these are not the only damage parameters responsible for yield reduction in sorghum (Singh et al. 1983; Pathak and Olela 1983; Taneja and Leuschner 1985b). Fast-growing sorghum genotypes with long and thin stems, but with fewer and longer internodes, short peduncles, and yellowish-green leaves with high trichome density have also been reported to be associated with resistance to C. partellus (Singh et al. 1983; Patel and Sukhani 1990). However, the present studies suggested that leaf feeding score, leaf glossiness, peduncle tunneling, number of stem borer holes plant $^{-1}$, overall resistance score, stalk length, number of nodes plant $^{-1}$, and days to panicle initiation are associated with stem borer deadhearts, and the traits play an important role in characterization of resistance/susceptibility in sorghums to $C$. partellus.

Susceptibility to $C$. partellus is dominant over resistance in susceptible $\times$ resistant, and susceptible $\times$ tolerant crosses, while resistance is dominant over tolerance in the tolerant $\times$ resistant crosses (Pathak 1985). In the present studies, the $F_{1}$ hybrids suffered significantly lower damage than their parents in all cross combinations. However, the hybrids based on stem borer-resistant or susceptible CMS lines with -resistant restorers showed significantly lower deadheart formation as compared to the hybrids based on stem borer-resistant or susceptible CMS lines with susceptible restorers, suggesting that restorer lines influence the expression of resistance to stem borer. Similar influence of restorer lines on expression of resistance to C. partellus has also been reported by Dhillon et al. (2006).

The nature of resistance to stem borer is polygenic and partially dominant over susceptibility (Pathak 1985; Pathak and Olela 1983; Rana et al. 1984). Inheritance of resistance to foliar damage, deadheart, stem tunneling and number of exit holes has earlier been reported to be governed by additive gene action (Nour and Ali 1998). Present studies also suggested additive type of gene action in inheritance of leaf feeding 
and deadheart traits. However, Pathak (1990) reported that additive genes govern resistance to leaf feeding and stem tunneling, while both additive and non-additive genes are important in the inheritance of resistance to deadhearts. Number of exit holes internode ${ }^{-1}$ and peduncle damage had 36.6 and $44.2 \%$ heritability, respectively; and tunneling parameters were poorly inherited (6.4 to 16\%) (Rana et al. 1984). Borer resistance is a quantitative trait, largely governed by additive and non-additive genes. Epistatic gene effects are more pronounced under artificial borer infestation (Agrawal et al. 1990).

The present studies indicated that leaf feeding score and deadhearts are governed by additive type of gene action, while number of nodes, overall resistance score, days to panicle initiation, recovery resistance score, and stalk length have been found to be associated with resistance to spotted stem borer, and are governed by additive and dominance type of gene action. Their correlation and direct effects are in the same direction, and explained $65.3 \%$ of the variation for deadhearts, and thus, could be used to breed for resistance to spotted stem borer, $C$. partellus in sorghum. In respect of deadhearts, stem borer infestation has a direct effect, but other traits also have indirect effects through leaf glossiness, panicle initiation, peduncle tunneling, etc. However, recovery resistance in terms of productive tillers consequent to deadhearts play a significant role in raising the levels of tolerance. Thus, there is a need to increase the levels of resistance in CMS and restorer lines to derive hybrids with high degree of resistance to stem borer, but at the same time care should be taken not to choose undesirable agronomic traits.

Acknowledgements We thank entomology staff: V. Venkateshwara Rao, J. Raja Rao, Madhusudhan Reddy, K. Hareendranath, and S.V.N. Chandra for their help in data collection, and Drs. B.U. Singh and P.M. Gaur for their valuable comments.

\section{References}

Agrawal BL, Taneja SL, House LR, Leuschner K (1990) Breeding for resistance to Chilo partellus Swinhoe in sorghum. Insect Sci Appl 11:671-682
Alghali AM (1986) Effect of cultivar, time, and amount of Chilo partellus Swinhoe (Lepidoptera: Pyralidae) infestation on sorghum yield components in Kenya. Trop Pest Manage 32:126-129

Dhillon MK, Sharma HC, Pampapathy GB, Reddy VS (2006) Cytoplasmic male-sterility affects expression of resistance to shoot bug, Peregrinus maidis, sugarcane aphid, Melanaphis sacchari, and spotted stem borer, Chilo partellus. Sorghum Millets Newslett 47:66-68

Dhillon MK, Sharma HC, Folkertsma RT, Chandra S (2006) Genetic divergence and molecular characterization of shoot fly-resistant and -susceptible parents and their hybrids. Euphytica 149:199-210

Dhillon MK, Sharma HC, Ram Singh J, Naresh S (2005) Mechanisms of resistance to shoot fly, Atherigona soccata in sorghum. Euphytica 144:301-312

Hallauer AR, Miranda JB (1981) Quantitative genetics in maize breeding. Iowa State Univ. Press, Ames, Iowa, USA

Harris KM (1985) Lepidopterous stem borers of sorghum. In: Proceedings of the international sorghum entomology workshop, 15-21 July 1984, Texas A\&M University, College Station, Texas, USA. International Crops Research Institute for the Semi-Arid Tropics, Patancheru 502 324, Andhra Pradesh, India, pp 161-167

House LR (1985) A guide to sorghum breeding. International Crops Research Institute for the Semi-Arid Tropics, Patancheru 502324, Andhra Pradesh, India, pp 83-84

ICRISAT (1992) The medium term plan, vol 2. International Crops Research Institute for the Semi-Arid Tropics, Patancheru 502 324, Andhra Pradesh, India

Ingram WR (1958) The lepidopterous stalk borers associated with Gramineae in Uganda. Bull Entomol Res 49:367-383

Jotwani MG, Young WR (1972) Recent developments in chemical control of insect pests of sorghum. In: Rao NGP, House LR (eds) Sorghum in seventies. Oxford \& IBH Publishing, New Delhi, India, pp 251-256

Kempthrone O (1957) An introduction to genetic statistics. John Wiley \& Sons, Inc., New York, USA

Kishore P (1991a) Morphological factors responsible for conferring resistance in sorghum cultivars to the stem borer, Chilo partellus (Swinhoe). J Entomol Res 15:163-168

Kishore P (1991b) Relationship between parameters for damage (leaf injury and stem tunnelling) caused by the stem borer, Chilo partellus (Swinhoe) on grain yield of different sorghum cultivars. J Entomol Res 15:236-241

Nour AM, Ali AE (1998) Genetic variation and gene action on resistance to spotted stem borer, Chilo partellus (Swinhoe) in three sorghum crosses. Sudan J Agric Res 1:61-63

Patel GM, Sukhani TR (1990) Some biophysical plant characters associated with stem borer resistance in sorghum genotypes. Indian J Entomol 52:452-455

Pathak RS, Olela JC (1983) Genetics of host plant resistance in food crops with special reference to sorghum stem borers. Insect Sci Appl 4:127-134 
Pathak RS (1985) Genetic variation of stem borer resistance and tolerance in three sorghum crosses. Insect Sci Appl 6:359-364

Pathak RS (1990) Genetics of sorghum, maize, rice and sugarcane resistance to the cereal stem borer, Chilo ssp. Insect Sci Appl 11:689-699

Rana BS, Singh BU, Rao VJM, Reddy BB, Rao NGP (1984) Inheritance of stem borer resistance in sorghum. Indian J Genet 44:7-14

Reddy KVS (1983) Studies on the stem borer complex of sorghum in Kenya. Insect Sci Appl 4:3-10

Sharma HC, Nwanze KF (1997) Mechanisms of resistance to insects in sorghum. Information Bulletin No. 45. International Crops Research Institute for the SemiArid Tropics, Patancheru 502 324, Andhra Pradesh, India, p 51

Sharma HC, Taneja SL, Leuschner K, Nwanze KF (1992) Techniques to screen sorghum for resistance to insect pests. Information Bulletin No. 32. International Crops Research Institute for the Semi-Arid Tropics, Patancheru 502 324, Andhra Pradesh, India, p 48.

Sharma HC, Taneja SL, Kameswara Rao N, Prasada Rao KE (2003) Evaluation of sorghum germplasm for resistance to insect pests. Information Bulletin No. 63 . International Crops Research Institute for the SemiArid Tropics, Patancheru 502 324, Andhra Pradesh, India, p 177

Singh BU, Rana BS (1984) Influence of varietal resistance on oviposition and larval development of stalk-borer, Chilo partellus Swinhoe and its relationship to field resistance in sorghum. Insect Sci Appl 5:287-296

Singh BU, Rana BS (1989) Varietal resistance in sorghum to spotted stem borer, Chilo partellus (Swinhoe). Insect Sci Appl 10:3-27
Singh BU, Rana BS, Reddy BB, Rao NGP (1983) Host plant resistance to stalk-borer, Chilo partellus Swinhoe in sorghum. Insect Sci Appl 4:407-414

Stephens JC, Holland RF (1954) Cytoplasmic male sterility for sorghum seed production. Agron J 46:20-23

Taneja SL, Leuschner K (1985a) Methods of rearing, infestation and evaluation for Chilo partellus resistance in sorghum. In: Kumble V (ed) Proceedings of the international sorghum entomology workshop, 15-21 July, 1984, Texas A\&M University, College Station, Texas, USA. International Crops Research Institute for the Semi-Arid Tropics, Patancheru 502 324, Andhra Pradesh, India, pp 175-188

Taneja SL, Leuschner K (1985b) Resistance screening and mechanisms of resistance in sorghum to shoot fly. In: Kumble V (ed) Proceedings of the international sorghum entomology workshop, 15-21 July, 1984, Texas A\&M University, College Station, Texas, USA. International Crops Research Institute for the SemiArid Tropics, Patancheru 502 324, Andhra Pradesh, India, pp 115-129

Taneja SL, Woodhead S (1989) Mechanisms of stem borer (Chilo partellus) resistance in sorghum. In: International workshop on sorghum stem borers, 17-20 November 1987, ICRISAT Center, India. International Crops Research Institute for the Semi-Arid Tropics, Patancheru 502 324, Andhra Pradesh, India, pp 137-143

Woodhead S, Taneja SL (1987) The importance of the behaviour of young larvae in sorghum resistance to Chilo partellus. Entomol Exp Appl 45:47-54 